\title{
Pertanggungjawabaan Pidana Selebgram Dalam mempromosikan Judi Menurut UU ITE
}

\author{
Ventry Faomassi zega, Hernita Aruan' ${ }^{2}$, Roni Dear A Purba ${ }^{3}$, Mazmur Septian Rumapea ${ }^{4}$ \\ ${ }^{12}$ Fakultas Hukum, Universitas Prima Indonesia Medan \\ ${ }^{34}$ Universitas Prima Indonesia Medan \\ Email: hernitaaruan4@gmail.com ${ }^{1}$, ventrizega19@gmail.com ${ }^{2}$, mazmurpaulus20@ gmail.com ${ }^{3}$
}

\author{
Article Info \\ Article history: \\ Article Accepted: 09 July 2021 \\ Publication : 16 July 2021
}

Keywords:
celebgram,
gambling, UU ITE

\begin{tabular}{l}
\hline Article Info \\
\hline Article history: \\
Article Accepted: 09 July 2021 \\
Publication : 16 July 2021
\end{tabular}

Kata Kunci:

Selebgram. Promosi, judi, UU ITE.

\begin{abstract}
Perkembangan teknologi di Indonesia sangat berkembang pesat, semakin hari semakin berubah fungsi dari mencari informasi sekarang digunakan sebagai jalan mata pencaharian. Perkembangan teknologi menjadi salah satu faktor pendorong terjadinya kejahatan dengan menggunakan internet sebagai sarananya. Berbagai kejahatan atau tindak pidana yang berkaitan dengan informasi transaksi elektronik atau mengatur para pengguna informasi dan transaksi elektronik yang dilakukan dengan media elektronik diatur didalam undang undang ITE. Sehingga rumusan masalah yang diambil adalah bagaimana pengaturan pidana tentang perjudian di indonesia menurut KUHP dan bagaimana pertanggungjawaban pidana dalam mempromosikan judi menurut UU ITE. Metode yang digunakan dalam penelitian ini adalah yuridis normatif yaitu penelitian hukum yang mengkaji data sekunder sebagai bahan dasar untuk penelitian. Hasil penelitian menyatakan bahwa tindak pidana perjudian secara online diatur khusus dalam pasal 27 ayat $2 \mathrm{UU}$ Nomor 11 Tahun 2008 tentang informasi dan pada pasal 303 KUHP tentang perjudian biasa

Abstract

The development of technology in Indonesia is growing rapidly, the function of finding information is changing day by day to now being used as a way of livelihood. The development of technology is one of the driving factors for crime by using the internet as a means. Various crimes or criminal acts related to electronic transaction information or regulating users of information and electronic transactions carried out with electronic mediaare regulated in the ITE law. So that the formulation of the problem taken is how the criminalregulation of gambling in Indonesia according to the Criminal Code is and how is criminal responsibility in promoting gambling according to the ITE Law. The purpose of this study is to determine the criminal regulation of gambling in Indonesia according to the Criminal Code and accountability in promoting gambling according to the ITE Law. The results of thestudy stated that the crime of online gambling is specifically regulated in Article 27 paragraph 2 of Law Number 11 Year 2008 regarding information and in Article 303 of the Criminal Code concerning ordinary gambling.

This is an open access article under the Lisensi Creative Commons Atribusi-BerbagiSerupa 4.0 Internasional
\end{abstract}

\section{Corresponding Author: \\ Hernita Aruan ${ }^{2}$ \\ Fakultas Hukum, Universitas Prima Indonesia Medan \\ hernitaaruan4@gmail.com}

\section{PENDAHULUAN}

\subsection{Latar Belakang}

Teknologi di Indonesia bertumbuh sangat cepat terutama ditengah-tengah masyarakat sehingga mengubah cara berpikir,bersikap dan bertindak. Berkembangnya zaman teknologi 
informasi sangat dipengaruhi oleh dampak globalisasi. Teknologi terus berkembang semakin hari semakin berubah fungsinya yang mana dahulu sebagai tempat untuk mencari tau berbagai informasi sekarang dapat digunakan sebagai jalan mata pencaharian masyarakat dengan memanfaatkan teknologi media sosial. Disamping manfaat yang disediakan teknologi komunikasi serta informasi, oknum yang tidak bertanggung jawab banyak memanfaatkannya sebagai sarana melakukan kejahatan dunia maya dengan menggunakan internet sebagai medianya. Kejahatan dunia maya bisa terjadi dikarenakan internet merupakan kreasi manusia yang bersifat mudah diretas oleh orang-orang yang mempunyai keahlian di bidang itu.

Informasi transaksi elektronik atau disingkat ITE merupakan hukum yang mengatur berbagai kejahatan atau kriminal yang terkait informasi transaksi elektronik dan mengatur para pemakainya melalui penggunaan sarana atau media elektronik. Peraturan terkait disahkan guna membuat aturan dan memudahkan pemakaian serta tranksaksi elektonik yang sangat populer pada masa ini. Dirancangnya UU ITE bertujuan guna memberikan perlindungan bagi orangorang sebagai pengguna teknologi serta pihak-pihak terkait. Dalam rangka sebagai tindakan preventif serta memantau anomalitas yang bisa terjadi pada penggunaan teknologi. Perundangundangan ITE telah memiliki fungsi tersendiri maka lahirlah uu, yang terkait dengan informansi dan transaksi elektronik dalam UU nomor 11 tahun 2008 terkait penggunaan teknologi. Tindak kejahatan dalam dunia maya melalui penggunaan jaringan internet dikenal dengan istilah cybercrime. Kejahatan yang sering dilakukan melalui media internet adalah perjudian online (Gambling online).

Teknologi Informasi tersebut akhirnya banyak disalahgunakan menjadi sebuah media yang tepat guna melakukan tindakan melanggar hukum, seperti melakukan perjudian online melalui media internet. Perjudian menjadi semakin marak dilakukan oleh masyakarat setelah berekembangnya internet yang dapat dijadikan media bermain judi. Dikarenakan jenis permainan yang beragam serta dapat diakses dalam waktu 24 jam, akibatnya pengguna tidak membutuhkan waktu tersendiri untuk bermain judi. Telah diatur mengenai ancaman hukuman pidana bagi para pemain judi tetapi yang dilakukan disuatu tempat tertentu bukan secara daring terkait dengan pasal 303 KUHP Negara Indonesia. Psehingga pihak yang tertangkap basah memainkan judi dapat terkena hukum pidana berdasarkan peraturan yang ditetapkan.

Merujuk pada peraturan di Pasal 1 angka 1 UU ITE disebutkan yakni Instagram merupakan salah satu media informasi yang tercantum dalam aturan UU ITE. Karena itulah apabila terdapat pelanggaran pada penggunaan aplikasi Instagram dapat melanggar peraturan pada UU ITE. Promosi terkait judi online terus digencarkan oleh pihak yang tidak bertanggung jawab salah satunya melalui media Instagram melalui edorsement yaitu memposting gambar bermuatan judi melalui akun yang memiliki banyak followers, hal ini tentu saja bertentangan dengan peraturan ITE pasal 27 ayat 2.

Dijelaskan pada Pasal 27 ayat (2) bahwa pihak yang dengan sengaja bermaksud dan tidak memiliki hak untuk mendistribusikan, menyebarkan atau membolehkan pengaksesan informasi atau dokumen elektronik yang mengandung perjudian. Sedangkan dalam pasal 303 KUHP menjelaskan sebagai berikut : Pihak yang sengaja menyediakan akses untuk bermain judi serta menjadikannya sebagai profesi, atau bermaksud ikut andil dalam permainan, tanp memperdulikan persyaratan yang harus dipenuhi sesuai tata cara untuk menjadikan judi sebagai mata penvaharian.

Dengan ketentuan pasal uu ite dan kuhp diatas maka oknum-oknum yang mempromosikan situs tersebut dapat dikenakan sanksi pidana. Instagram yang memiliki jumlah pengikut yang banyak disebut sebagai SELEBGRAM yaitu istilah yang digunakan untuk pemilik akun instagram yang faimiliar atau sering terekspos di media tersebut. Istilah Selebgram merupakan gabungan dari kata "selebriti" serta "instagram" yang mempunyai banyak followers dimanfaatkan untuk mempromosikan berbagai macam produk dagangan yang dimiliki oleh si penjual dengan cara penjual membayar mahal kepada selebgram untuk mempromosikan produk tersebut di instagram nya sehingga followers nya pun mengikuti akun si penjual tersebut. 
Promosi yang disebut diatas dikenal dengan endorse. Endorse merupakan salah bentuk promosi yang sedang marak dilakukan adalah suatu bentuk dukungan atau support dari pada artis media kepada suatu produk atau bentuk kerjasama dengan berbagai pihak dengan tujuan guna melakukan promosi suatu produk yang ditawarkan yang menawarkan keuntungan bagi kedua belah pihak. Perkembangan dan kemajuan teknologi informasi telah melahirkan sistem promosi secara online sehingga telah mengubah kehidupan masyarakat dengan tidak sengaja. Dalam hal pemanfaatan teknologi informasi untuk berbagai keperluan, wajib disertakan dengan peraturan-peraturan yang dapat mengatur penggunaannya yang akibatnya dalam menggunakan teknologi, seseorang tetap mengedepankan etika sosial dan agama serta peraturan undangundang.

Perbuatan mempromosikan judi menggunakan media Instagram sangat gencar dilakukan oleh akun-akun penggunanya dengan ribuan bahkan jutaan pengikut, identik dengan wanita dengan pakaian terbuka namun dibayar dengan harga yang fantastis untuk melakukan iklan yang terkait dengan judi online, meskipun judi merupakan perbuatan melanggar hukum yang dapat memberikan kerugian untuk konsumen. Perbuatan mengiklankan judi menggunakan media Instagram berdampak negatif karena pihak yang sebelumnya tidak mengenal tentang judi online pada akhirnya mengetahui dan bahkan mengikuti judi tersebut.

Berdasarkan penjelasan sebelumnya maka peneliti merasa perlu untuk mengangkat permasalahan ini dalam penelitian dengan judul "Pertanggungjawaban Pidana Selebgram Dalam Mempromosikan Akun Judi Menurut Uu Ite"

\subsection{Rumusan Masalah}

1. Bagaimana pengaturan pidana tentangperjudian di indonesia menurut KUHP?

2. Bagaimana pertanggungjawaban pidana dalam mempromosikan judi menurut UU ITE?

\subsection{Tujuan peneltian}

1. Untuk mengetahui pengaturan pidana tentang perjudiaan di Indonesia menurut KUHP

2. Untuk mengetahui pertanggungjawaban dalam mempromosikan judi menurut UU ITE.

\section{METODE PENELITIAN}

\subsection{Jenis Penelitian}

Melalui metode pendekatan secara yuridis normatif, peneliti akan menganalisis inti permasalahan berdasarkan lingkupan dan pemahaman terkait permasalahan yang telah dirincikan sebelumnya. Pendekatan doctrinal research atau metode yuridis normatif merupakan metode yang dilakukan menggunakan kajian hukum melalui penelaahan terkait teori. Konsep, dasar hukum serta aturan Undang-undang yang berkaitan dengan riset ini, penelitian ini juga disebut dengan penelitian kepustakaan, dilakukan dengan cara memahami referensi seperti buku-buku, aturan Undang-undang serta catatan lainnya yang berkaitan dengan riset yang dilakukan.

Adapun sifat dari riset ini yaitu deskriptif analitis. Karena riset ini diselenggarakan dengan menyajikan representasi mempelajari, mendeksripsikan, dan menguraikan peraturan hukum tertentu.

\subsection{Sumber Bahan Hukum}

Digunakan data yang dalam rangka berjalannya riset ini yakni jenis data sekunder, adalah data didapatkan melalui kepustakaan karena penelitian hukum yang diperoleh dari bahan literatur yang terkait dengan catatan dokumen formal, buku-buku yang diterbitkan, Undangundang, artikel dan karya ilmiah, dan dokumen resmi yang berhubungan dengan penelitian yang dilakukan. Terkait bahan hukum sekunder, hal ini dapat dijabarkan menjadi tiga bahan yakni:

a) Terkait bahan hukum yang bersifat saling mengikat disebut sebagai Bahan Hukum Primer.

Sedangkan jenis bahan hukum yang dipakai pada riset ini adalah peraturan Undang-undang yang terkait dengan :

1. Terkait Peraturan Perundang-Undangan mengenai Transaksi Elektronik serta Teknologi informasi No. 11 Pada tahun 2008 
2. KUHP (Kitab Undang-Undang Hukum Pidana)

3. Peraturan Negara lain yang berkaitan dengan riset.

b) Berkaitan dengan pembahasan yang mempunyai hubungan dengan pokok penelitian dibahas pada riset yang didapatkan dari karya imliah, buku, serta internet.

c) Terkait dengan bahan hukum dimiliki yang memperkuat bahan hukum primer dan sekunder yang bisa menjelaskan serta memberikan pemahaman terkait bahan hukum lain disebut sebagai Bahan Hukum Tersier. Penulis menggunakan jenis bahan hukum pada riset tersebut adalah kamus hukum, kamus besar bahasa Indonesia, juga Ensiklopedia terkait dengan pokok pembahasan.

\subsection{Teknik Pengumpulan Data}

Riset ini menggunakan metode pengumpulan melalui studi pustaka, yakni metode yang dilakukan dengan mendapatkan data melalui pengkajian pustaka seperti hasil penelitian, makalah dan jurnal ilmiah, serta lietratur lainnya terkait penelitian. Pada jenis penelitian hukum normatif, dilakukan pengumpulan data dengan meneliti data pustaka dan data sekunder terkait pokok penelitian.

\subsection{Analisis data}

Setelah memperoleh data menggunakan metode studi pustaka, selanjutnya data tersebut dianalisis dengan metode kualitatif. Teknik analisis kualitatif dikerjakan melalui pendeksripsian dan penjabaran data dan temuan di lapangan yang kemudian dipahami, didefinisikan, dan dievaluasi. Selanjutnya dilakukan analisis data menggunakan tehnik induktif, yang merupakan tehnik berfikir yang dilakukan atas dasar data dan fakta secara umum yang ditemukan, kemudian ditraik kesimpulan bersifat lebih khusus guna memberikan gagasangagasan, dan hasil interpretasi data tersebut selanjutnya dianalisis menggunakan metode pemaparan data dalam bentuk kalimat dan paragraf guna menjawab bab selanjutnya.

\section{HASIL PENELITIAN DAN PEMBAHASAN}

\subsection{Pengaturan Pidana Tentangperjudian Diindonesia menurut KUHP}

Seiring berkembangnya teknologi telah membawa dampak terhadap maraknya kejahatan yang menggunakan teknologi modern, meskipun jenis kejahatannya sama, namun dengan wahana permainan atau mesin permainan yang berbeda, akan tetapi manusia tidak menggunakan media permainan yang baru tersebut dengan baik. Sehingga sangat penting terdapat media hukum seperti Undang-undang, dikarenakan bahwa hukum dianggap mampu mengatasi tindak kejahatan Dalam pengaturan pidana tentang perjudian di indonesia menurut KUHP terlebih dahulu kita harus mengenal perbedaan dari defenisi perjudian biasa (secara langsung) dan perjudian secara online dibawah ini dijelaskan lebih mendetail terkait penjelasan tersebut.

\subsubsection{Perjudian Biasa (secara langsung)}

Permainan yang mempertaruhkan uang dalam permainannya berdasarkan Kamus Besar Bahasa Indonesia disebut dengan istilah judi atau perjudian. Berjudi adalah permainan mempertaruhkan uang atau barang berharga lain dalam permainan adu nasib, yang mempunyai maksud untuk memperoleh lebih banyak harta ataupun uang yang dipertaruhkannya. Dikatakan bahwa perjudian secara umum merupakan tindakan melawan hukum pidana karena menguntungkan pihak yang menang dan merugikan pihak yang kalah atau dalam definisi lain disebut dengan permainan yang mempertaruhkan keberuntungan. Judi bersifat mengandung ketidakjelasan, kebetulan, dan tidak pasti sehingga tidak layak dijadikan pekerjaa.

Perjudian diatas telah menimbulkan masalahbagi masyarakat yang dapat merugikan moral, kemalasan karena berserah pada keuntungan saja sehingga pada dasarnya kejahatan ini berdampak pada terganggunya kemanaan dan ketentraman masyarakat secara umum. Berdampak pula pada perkembangan psikologis dan kehidupan anak-anak, mereka yang biasa melihat perjudian di lingkungan tempat tinggal menjadi pensaran dan ingin ikut mencoba permainan tersebut yang akhirnya 
anak-anak melakukan tindak melawan hukum pidana, pastinya hal ini berdampak buruk bagi perkembangan dan psikologis anak karena lingkungan yang buruk tersebut, di lain sisi juga menyebabkan kerugian bagi pihak yang bermain dengan judi.

Masalah perjudian telah lama menjadi problema dalam kehidupan di Indnesia, itu bukanlah hal yang baru. Sehingga, perkembangan permainan judi sebaiknya diperhatikan lebih serius oleh para penegak hukum dalam rangka mewujudkan kehidupan bermasyarakat yang tentram dan demi kemajuan perekenomian negara. Sampai sekarang, penanganan hukum pidana terkait perjudian masih belum efektif, apalagi seiring kemajuan zaman, jenis perjudian semakin kompleks, sehingga aparat penegak hukum masih sulit untuk menanganinya.

Jika ditinjau dari KUHP, perjudian disebutkan sebagai tindak pidana yang ditertibkan pada pasal 303 KUHP disebutkan bahwa perjudian adalah bentuk permainan yang mengandung ketidakjelasan, kemungkinan bisa memperoleh keuntungan dan terkadang juga mengalami kerugian tergantung keberuntungan pemainnya. Dikategorikan tindak pidana yang disengaja tanpa ada unsur ketidaksengajaan atau pidana dolus dikarenakan pihak yang memainkan judi menyadari dan secara nyata mengetahui bahwa mereka sedang melakukan permainan judi.

Dalam peraturan KUHP pasal 303 sangat jelas disebutkan jika perjudian itu dilarang. Pihak yang secara sadar menawarkan dan menyediakan kesempatan untuk masyarakat umum guna bermain judi dan menjadikannya sumber pendapatan, atau ikut andil dalam perusahaan perjudian sendiri tanpe memperdulikan dilakukannya perjudian karena ada kesempatan atau terdapat syarat yang harus dilengkapi dengan cara apapun dan apabila menjadikan judi sebagai sumber penghasilan.

Merujuk pada pasal 303 dijelaskan mengenai elemen-elemen tindak pidana perjudian yaitu :

a. Adanya perbuatan

Mengenai perbuatan yang dimaksudkan yaitu tiap-tiap perangai dalam memainkan suatu permainan baik hal tersebut secara langsung diaplikasikan oleh pribadinya, seperti permainan dadu, domino, ulo, dan sebagainya serta seperti permainan yang diadakan oleh orang lain tapi diikuti oleh mereka seperti permainan sepak bola.

b. Berdasarkan keberuntungan semata

Maksudnya adalah, kemenangan yang diperoleh semata-mata karena faktor keberuntungan dan selalu dipenuhi imajinasi ingin memenangkan permainan. Dengan kata lain, hanya menggantungkan nasib pada faktor keberuntungan semata, atau berdasarkan pengalaman para pemain judi yang sudah biasa.

c. Adanya objek yang dipertaruhkan

Dalam permainan judi, pasti terdapat barang taruhan yaitu benda berharga seperti uang dan harta baik yang diselenggarakan oleh diri sendiri atau dibuat oleh pihak yang ikut bermain judi, pihak yang menang akan mendapatkan harta yang dipertaruhkan sehingga ada pihak yang diuntungkan serta ada juga yang dirugikan.

d. Tindak pidana

Tiap permainan judi tidak mendapatkan izin dari pemerintah atau pihak yang berwewenang, sehingga hal tersebut ilegal untuk dilakukan. Namun apabila suatu tindakan telah mendapat izin resmi dari pemerintah, hal tersebut bukanlah menjadi tindak pidana. Jika melakukan tindak pidana termasuk perbuatan melawan hukum dan harus dikenakan sanksi.

\subsubsection{Perjudian online (secara daring)}

Judi online pertama kali ada pada tahun 1994 yang berasal dari lolosnya kebenaran informasi terkait perdagangan bebas yang dilakukan Negara Karibia Antigua serta Barbuda yang akibatnya memberi izin untuk organisasi yang lain untuk bisa membuka situs judi online. Perjudianonline merupakan permainan yang dilakukan 
menggunakan uang sebagai taruhan adanya ketentuan permainan terdapat juga jumlah taruhan yang ditentukan oleh pelaku permainan judi online, serta menggunakan media elektronik dengan akses internet sebagai perantara bisa diakses di tempat manapun serta kapanpun yang diinginkan tak terbatas waktu karena menggunakan jaringan internet

Induk dari permainan judi online yaitu cybercrime dan cyberspace. Perkembangan teknologi informasi dan jaringan komputer global atau internet semakin cepat sehingga telah menciptakan hal baru yang dinamakan cyberspace. Dunia yang berlandaskan komunikasi daring yang dapat diakses menggunakan komputer yang memasarkan situasi baru yaitu dalam bentuk virtual disebut dengan cyberspace. Meskipun pada realitanya, manusia mustahil berada pada dua atau lebih sisi kehidupan, namun melalui teknologi dunia maya dapat mencangkup beberapa lini kehidupan sehingga memungkinkan terjalinnya hubungan tanpa dipermasalahkan oleh situasi, kondisi, jarak serta wilayah.

Perjudian melalui teknologi informasi dan tarnsaksi elektonik saat ini sedang marak dilakukan, jenis permainan yang paling sering dilakukan pada jenis olah raga dan permaianan kasino. Dampak dari perkembangan teknologi yang semakin canggih memberikan peluang masyarakat untuk dapat bermain judi online. Adanya iklan yang sering muncul di Instagram,facebook dan media platform social lainnya. Gagasan pemanfaatam sarana teknologi sebagai wadah dilakukannya judi online diawali dengan pemasaran melalui SMS yang dikirim random ke setiap orang, sampai pada perjudian yonline berbasis aplikasi Seperti Mesin slot, Casino, Domino, Poker dan lain sebagainya. Melalui perjudian secara online, pemain judi bisa bermain dengan pihakpihak lain diluar wilayah Indonesia dan seluruh penjuru dunia. Perjudian online dalam proses taruhannya dan pengumpulan uang diakukan melalui jaringan internet. Akan tetapi judi online yang sering digunakan oleh masyarakat adalah Poker, jenis permainan yang menggunakan kartu remi dengan cara mendapatkan kombinasi kartu terbaik dan kedua adalah Domino, yaitu permainan judi yang menggunakan kartu domino dan harus mendapat nilai tertinggi dengan menjumlahkan kedua kartu.

Promosi adalah salah stau bentuk taktik para bandar judi dalam melakukan hubungan komunikasi transaksi dengan konsumennya. Kegiatan promosi digunakan sebagai alat untuk memberikan informasi kepada orang lain atau pembeli tentang sebuah jasa atau produk. Dalam melakukan promosi perjudian online maka dimanfaatkan lah media sosial sebagai perantara melakukan promosi tersebut. Teknik dalam melakukan promosi dengan menggunakan sosial media yang cukup dikenal adalah instagram yaitu pemilik situs akan membayar pemilik akun sosial yang memiliki followers banyak serta mempunyai kriteria menarik dan diwajibkan untuk memposting tentang informasi situs judi online tersebut dalam tautan mereka.

Pada peraturan hukum yang berlaku di Negara Indonesia, perbuatan melanggar hukum pidana terkait perjudian klasik dengan perjudian modern melalui dunia maya dibedakan. Hukum pidana bagi yang melakukan aktivitas perjudian secara daring, secara spesifik dijelaskan dalam pasal 27 ayat 2 UU nomor 11 tahun 2008 terkait Informasi serta Transaksi Elektronik, di sisi lain, perjudian klasik diatur secara umum berdasarkan peraturan yang termaktub pada pasal 303 KUHP. Dinyatakan pada Pasal 27 ayat (2) tentang perbuatan tindak pidana kegiatan perjudian melalui dunia maya, secara umum dijelaskan dalam Pasal 27 ayat (2) disebut sebagai aktivitas terlarang atau setiap indivdu yang secara sengaja dan tidak memiliki izin untuk menyebarkan atau mentransmisikan serta memudahkan akses informasi dan dokumen elektronik yang mengandung unsur perjudian. Kemudian pada BAB XI terkait "Ketentuan Pidana", Pasal 45 ayat (1) yang berbunyi: Ayat (1): Tiap individu yang mencangkup syarat seperti yang dimaksud dalam Pasal 27 ayat (1), ayat (2), ayat (3), atau ayat (4) dijatuhi hukum pidana dengan penjara paling lama 6 (enam) tahun dan/atau denda sebanyak banyaknya Rp. 1.000.000.000,00 (satu miliar rupiah). 
Pada peraturan pasal 27 ayat (2) dijelaskan bahwa perjudian dilarang karena terdapat tiga unsur yakni, menyalurkan atau mentransmisikan serta memudahkan tersalurkannya akses informasi atau dokumen online yang memuat unsur perjudian atau gambling, yakni:

Penyaluran atau kata lainnya yaitu mendistribusikan dengan suku kata "distribusi" memiliki arti "menyalurkan atau mengirimkan sesuatu kepada pihak lain atau ke banyak tempat." Dari kata dasar tersebut terbentuklah kata kerja menjadi "mendistribusikan" dengan arti menyalurkan atau mengirimkan sesuatu kepada pihak lain atau ke banyak tempat. Terkait dengan unsur perjudian, maka kegiatan menyalurkan ini terkait dengan pengiriman informasi secara digital yang mengandung unsur perjudian secara disengaja.

Sedangkan kata "Mentransmisikan" berasal dari suku kata "transmisi" berarti mengirimkan sesuatu, menyebarluaskan pesan atau iklan dari satu pihak ke pihak lain. Kedua sifat yang telah dijabarkan seperti mendistribusikan dan mentransmisikan yaitu tujuannya untuk menyalurkan informasi kepada target penerima. Karena itulah, guna melihat apakah perbuatan tersebut sudah dilakukan dengan baik sesuai target, terlihat dari sisi tersalurkannya informasi yang disampaikan. Dalam aspek informasi yang dimaksud akan disebarkan melalui penggunaan hardware atau software berdasarkan sistem harus dapat disalurkan kepada target penerima.

Memudahkan tersalurnya akses dimaksudkan sebagai perbuatan yang berbentuk apapun yang mengakibatkan terdistribusinya informasi online kepada target penerima dengan media komputer sebagai alat menyusun informasi. Akses memiliki arti gerbang masuk atau tol. Kata ini dipakai karena terkait dengan bentuk perbuatan penggunaan teknologi informasi dengan komputer yang memudahkan jalan tersampaikannya informasi ekeltronik yang sengaja disebarkan.

\subsubsection{Pertanggungjawaban Pidana Selebgram Dalam Mempromosikan Akun Judi Menurut UU ITE}

Perkembangan teknologi dijaman sekarang memudahkan seseorang mendapatkan uang secara instan. Kemajuan tersebut telah mengubah fungsi media social sebagai sarana produksi informasi penting untuk masyarakat. Sebagai contoh kemajuan teknologi dalam dunia media social adalah promosi judi online, dahulu judi dimainkkan secara langsung akan tetapi sekarang dapat digunakan melalui jaringan online saja. Promosi tersebut menyebabkan masalah dalam dunia hukum. Pengguna sosial media yang mempunyai banyak pengikut atau disebut dengan selebgram sering menerima endorse untuk mempromosikan barang atau jasa. Endorse merupakan hal yang sedang trend di Instagram dan di berbagai kalangan selebgram, pemilik/penjual produk dagangan atau usaha memberikan bayaran kepada selebgram untuk mempromosikan produk dagangan nya dan kemudian selebgram mempromosikan produk tersebut.

Pengertian promosi itu sendiri adalah memperkenalkan dan menyebarkan informasi tentang produk tertentu untuk menarik minat masyarakat untuk membeli..Dalam mempromosikan permainan judi oleh selebgram pertama-pertama kita harus mengenal yang namanya penyebaran dalam dunia media social (Medsos). Pendistribusian merupakan ciri lainnya dalam kehidupan dunia maya. Hal ini mengindikasikan bahwa pengguna internet aktif dalam menyebarkan per konten yang telah terekspos dalam internet. Penyebaran terjadi dalam dua jenis. Pertama melalui konten, setiap program yang terdapat di platform sosial media secara tidak langusung ikut mempublikasikan konten penyebaran judi online. Kedua melaui gawai, dimana penyebarannya nampak dari segi dimana aplikasi media sosial memiliki tombol "bagikan" yang juga terdapat di Instagram. Akibat dari penyebaran tersebut adalah para pengikut atau penggunan Instagram lainnya menggunakan permainan tersebut dan tak sedikit menggunakannya sebagai mata pencarian. 
Pengusaha Judi dalam mencapai sasaran produknya mereka menggunakan selebgram sebagai alat untuk promosi permainan judi tersebut. Biasanya pengguna Instagram yang memiliki banyak followers dan biasanya berpakaian seksi dan terbuka menjadi buruan oleh para pengusaha judi. Semakin berkembangnya kegiatan perjudian yang juga dapat dilakukan secara daring dengan penggunaan internet sebagai medianya membuat perjudian menjadi susah untuk dibasmi, karena perjudian secara online bisa dilakukan oleh pihak manapun dan sulit terdeteksi. Adanya perjudian jenis baru melalui jaringan internet, mengakibatkan perjudian semakin susah untuk dihilangkan dari Indonesia, dikarenakan tindakan itu bisa dilakukan siapa saja, tanpa memandang tempat sekalipun. Selebgram mempromosikan akun atau situs judi online tersebut melalui sebuah video, atau konten.Padahal mempromosikan perjudian melalui instagram ini adalah kejahatan dunia maya.Perbuatan selebgram yang mempromosikan judi merupakan pelaku tindak pidana karena melakukan kejahatan cyber.Selebgram yang mempromosikan bisa dikelompokkan menjadi seorang pelaku yang memberikan bantuan atas perbuatan melawan hukum pidana yang berkaitan dengan UU ITE Nomor 11 Tahun 2008.

\section{Contoh kasus}

Sebagai salah satu contoh selebgram yang memiliki banyak pengikut dan mempromosikan judi ialah MK, akan tetapi polisi telah menangkap selebgram berinisial MK tersebut yang berasal dari bengkulu dan memiliki 118 ribu pengikut di Instagram. Perempuan 20 tahun itu dibekuk petugas lantaran mempromosikan situs judi online di akun Instagram pribadinya.Ketika selebgram tersebut mempromosikannya, selebgram asal Bengkulu itu memberikan berupa kode cashback senilai Rp 50 ribu untuk para pendaftar baru. Kode itu disampaikan dalam video yang ia buat.Polisi menyita barang bukti 1 unit telepon genggam, buku tabungan, dan kartu SIM.Atas perbuatannya MK dinyatakan melanggar peraturan Pasal 45 Ayat (2) juncto Pasal 27 Ayat (2) Undang-Undang Nomor 19 Tahun 2016 yang terkait pelanggaran Informasi serta Transaksi Elektronik "Tersangka melakukan perbuatan melanggar hukum pidana secara sengaja serta tidak memiliki izin untuk menyelurkan serta mentransmisikan dokumen serta informasi elektronik yang mengandung unsur perjudian dijerat pidana paling lama 6 tahun penjara serta wajib membayar denda sebanyak-banyaknya Rp1 miliar.

\subsubsection{Pertanggungjawaban dalam UU ITE}

Pelaku usaha judi online yang mengedarkan tanpa izin, disebutkan dalam pasal 27 ayat 2 dinyatakan tiap-tiap individu yang secara disengaja serta tidak memiliki izin untuk menyalurkan, mentransmisikan serta memudahkan akses terkait informasi serta dokumen elektronik yang mengandung unsur perjudian. Kemudian lebih lanjut diterangkan pada ketetapan hukum pidana dalam Bab XI pasal 45 ayat (1) menyatakan bahwa tiap individu yang memenuhi persyaratan yang termaktub dalam pasal 27 ayat (1), ayat (2), ayat (3) atau ayat (4) dijatuhi hukuman pidana dengan dipenjara selamalamanya 6 (enam) tahun dan/ atau denda sebanyak-banyaknya Rp1.000.000.000,00 (satu miliar rupiah). Dalam hukum pidana, konsep tanggung jawab adalah konsep inti. Dalam doktrin latin "actus non facit reum, nisi mens sit rea, yang artinya sesuatuperbuatan tidaklah menjadikan seseorang dinyatakan salah terkecuali apabila dikerjakan dengan ada niatan jahat.

Namun dalam pasal 27 ayat 2 diatas masih terdapat celah hukum oleh oknum-oknum yang tidak dijabarkan pada pasal diatas, namun memiliki keterlibatan pada aktivitas perjudian di dunia maya. Seperti para pemain judi yang memakai atau mendapat jalan informasi atau dokumen yang mempunyai unsur judi. Apabila aparat mempunyai sifat konsisten untuk memberantas tindak aktivitas judi di Indonesia, semestinya judi online disetarakan dengan perjudian konvensional 
dimana para penjudi juga ditindak hukum pidana selain pidana yang dijatuhkan untuk para bandarnya.

Mayoritas negara bagian di negara Amerika Serikat melegalkan aktivitas permainan judi, meskipun banyak pula negara bagian lainnya yang mengilegalkan judi online karena permainan judi secara daring bisa mengakibatkan datangnya bahaya untuk masyarakat dan merugikan negara bagian yang terkait. Dasar pelarangan tersebut didasarkan pada hal-hal berikut ini:

1. Dapat terindikasi adanya kecurangan di Internet

2. Memungkinkan khususnya untuk anak-anak dibawah umur masuk ke dalam jaringan perjudian

3. Mengakibatkan kecanduan bagi pengguna dan masyarakat

4. Dapat mengurangi keuntungan atau pendapatan dari negara yang memiliki perjudia legal atau resmi.

Berdasarkan hal-hal tersebut diatas, Indonesia seharusnya lebih juga menekankan kepada para penjudi pengguna situs perjudian daring yang dimaksud agar dapat dihukum. Dalam pasal 27 ayat 2 UU ite bagi para pihak yang memperkenalkan situs tersebut maka akan dipidana. Akan tetapi di Instagram masih banyak akun para selebgram yang mempromosikan situs judi ilegal tersebut. Para selebgram yang mengabil keuntungan tersebut dapat dikenakan sansksi pidana sesuai pasal UU ite diatas.

\section{KESIMPULAN}

1. Pengaturan pidana tentangperjudian di indonesia menurut kuhp dibedakan menjadi dua yaitu perjudian biasa dan perjudian secara online, perbuatan pidana yang dilakukan secara daring berbeda dengan tindakan pidana permainan judi secara langsung. Secara spesifik diatur pada pasal 27 ayat 2 UU nomor 11 tahun 2008 terkait informasi serta permainan judi klasik diatur dalam Pasal 303 KUHP.

2. Pertanggungjawaban dalam mempromosikan judi menurut UU ITE diatur pada Undangundang Nomor 11 Tahun 2008 pasal 27 ayat 2 disebutkan dalam pasal ini yaitu setiap individu yang secara sengaja serta tidak memiliki izin untuk menyalurkan, mentransmisikan serta memudahkan akses informasi dan dokumen elektronik yang memiliki unsur perjudian. Diatur juga didalam ketentuan hukum pidana Bab XI pasal 45 ayat (1) diatur bahwa "Setiap orang yang memenuhi unsur sebagaimana dimaksud dalam pasal 27 ayat (1), ayat (2), ayat (3) atau ayat (4) dipidana dengan pidana penjara paling lama 6 (enam) tahun dan/ atau denda paling banyak Rp1.000.000.000,00 (satu miliar rupiah).

\section{UCAPAN TERIMAKASIH}

Puji syukur kehadirat Tuhan Yang Maha Esa, atas Berkat Rahmat dan Karunia-Nya, sehingga peneliti dapat menyelesaikan jurnal dengan judul : "Pertanggungjawaban Pidana Selebgram Dalam Mempromosikan Akun Judi Menurut UU ITE”. Tujuan penulisan Jurnal ini untuk memenuhi sebahagian syarat memperoleh gelar Sarjana Hukum (S.H) bagi mahasiswa program S-1 di program studi Ilmu Hukum Jurusan Hukum Universitas Prima Indonseia. Peneliti menyadari bahwa jurnal ini masih jauh dari kesempurnaan, oleh sebab itu peneliti mengharapkan kritik dan saran yang bersifat membangun dari semua pihak demi kesempurnaan jurnal ini.

Terselesaikannya jurnal ini tidak terlepas dari bantuan banyak pihak, sehingga pada kesempatan ini dengan segala kerendahan hati dan penuh rasa hormat kami peneliti menghaturkan terima kasih yang sebesar-besarnya bagi semua pihak yang telah memberikan bantuan moril maupun materil baik langsung maupun tidak langsung dalam penyusunan jurnal ini hingga selesai, terutama kepada yang kami hormati:

1. Ibu Dr. Elvira Fitriyani Pakpahan, S.HI., M.Hum, selaku Dekan Fakultas Hukum yang telah memberikan kesempatan bergabung dalam keluarga besar fakultas hukum 
Universitas Prima Indonesia.

2. Ibu Dewi Ervina Suryani, S.H., M.H., selaku Ketua Program Studi Fakultas Hukum yang telah meluangkan waktu memberikan masukan serta dukung dalam penyelesaian jurnal ini.

3. Bapak Mazmur Septian Rumapea, S.H., M.H., selaku Dosen Pembimbing yang telah banyak membantu dan meluangkan waktu, tenaga dan pikiran selama bimbingan untuk memberikan masukan maupun kritik kepada peneliti hingga jurnal ini dapat diselesaikan tepat waktunya.

4. Seluruh Dosen yang tidak dapat satu persatu peneliti cantumkan dalam jurnal ini terimakasih telah mengajar dan memberikan banyak ilmu kepada kami selama mengikuti perkuliahan di Fakultas hukum Universitas Prima Indonesia.

5. Bapak Rizki, S.H., M.Kn., Selaku Bagian Staff Admin Fakultas hukum Unpri yang membantu segala proses memberi masukan dan memberi info dalam penyelesaianjurnal ini.

6. Kak Maritta siregar., Selaku Bagian Staff Admin Fakultas Hukum Unpri yang telah banyak membantu dalam hal-hal yang berkaitan dengan administrasi dalam penyelesaian jurnal ini.

7. Kedua orangtua yang selama ini telah mendampingi,mendoakan serta memberikan dukungan yang luarbiasa kepada peneliti baik dalam hal materil maupun non materil dalam segala hal yang peneliti lakukan, khususnya dalam penyelesaian jurnal ini.

8. Kepada Teman-teman dan sahabat para peneliti yang telah memberi ide-ide, kritikan, dan semangat serta waktu untuk menemani menyelesaikan jurnal ini.

9. Semua pihak yang turut membantu hingga selesainya skripsi ini yang tidak dapatpenulis sebutkan namanya satu persatu. Akhir kata semoga skripsi ini dapat bermanfaat bagi kita semua. Mohon maaf apabila ada kekhilafan dalam penulisan ini.

Akhir kata semoga jurnal ini dapat bermanfaat bagi kita semua. Mohon maaf apabila ada kekhilafan dalam penulisan ini.

\section{DAFTAR PUSTAKA}

Khairul Anam, "Hacking vs hukum Positif \& Hukum Islam”, Yogyakarta: Sunan Kalijaga Press, 2010, hal. 3.

Undang-undang ite: pengertian ite dan uu ite (cyberpathe. blogspot.com) diakses pada hari kamis 3 juni 2021 pukul 15:32 WIB

Jesslyn, "Pertanggungjawaban penerima endorse judi dan kosmetik illegal melalui Instagram", lex librum: jurnal ilmu hukum, Vol 6 No 2,2020

Kitab Undang-Undang Hukum Pidana Pasal 303

https://www.tokopedia.com/blog/mau-terkenal-di-instagram-ini-cara-menjadiselebgram/diakses pada hari jumat, 18 juni 2021, pukul 18:04 WIB

https://ekspetasi.com/arti-endorse/ diakses pada hari kamis, 3 juni 2021, pukul 13:45 WIB.

https://idtesis.com/metode-penelitian-hukum-empiris-dan-normatif/ diakses pada hari kamis tanggal 24 juni 2021 pukul 19:33 WIB.

Soerjono Soekanto, "Pengantar penelitisn hukum", UI Press, Jakarta, 1986, hal 6

Soerjono Soekanto dan Sri Mamudji, "Penelitian hukum normative, suatu tinjauan singkat", Raja Grafindo Persada, Jakarta, 2011

Mohammad Kholid, "Kriminalisasi Persiapan Melakukan Tindak Pidana Sebagai Bentuk Penanggulangan Kejahatan Sendiri Mungkin”, Jurnal Mahkamah, Vol XX, No. 1 April 2008

Poerwardamninta,"Kamus Besar Bahasa Indonesia Edisi Kedua",(Jakarta: Balai Pustaka)

http://repository.unissula.ac.id/12215/2/babI.pdf diakses pada jumat 18 juni 2021 pukul 18:39

Mesias J.P sagala "Tinjauan yuridis terhadap tindak pidana permainan judi jackpot (studi kasus putusan nomor 45/pid.b/2017/pn.mdn) jurnal hukum kaidah Volume: 18, Nomor:3

http://e-journal.uajy.ac.id/3586/2/1HK09504.pdf diakses pada sabtu 19 juni 2021 pukul 16:59 
http://e-journal.uajy.ac.id/3586/2/1HK09504.pdf diakses pada sabtu 19 juni 2021 pukul 17.20 http://e-journal.uajy.ac.id/3586/2/1HK106632.pdf diakses pada sabtu 19 juni 2021 pukul 17.41 Mustofa Hasan, Pengantar Hukum Keluarga (Bandung: Pustaka Setia, 2011)

Komang dan Wayan "Penerapan Pasal 303 kuhp dalam putusan tindak pidana perjudian di pengadilan negri Denpasar (analisis putusan nomor 716/pid.b/2018/pn dps)" jurnal kertha wicara vol. 9 no. 7 Tahun 2020

Pande, A.A. Sagung dan I Putu Gede, "Sanksi Pidana Terhadap Para Pemasang Dan Promosi Iklan Bermuatan Konten Judi Online”, jurnal preferensi hukum, Vol. 2 No. 1 Februari 2021

Christianata, "perjudian online dalam perspektif undang-undang nomor 11 Tahun 2008 tentang informasi dan transaksi elektronik", jurnal teknologi informasi,

Pusat Bahasa, Kamus Besar Bahasa Indonesia (Jakarta: Gramedia Pustaka Utama, 2008)

Muhammad, Fanny dan Samuel, "Perjudian Online: Kajian Pidana atas Putusan Nomor 1033/PID.B/2014/PN.BDG”, Lentera Hukum, Volume 4 Issue 1 (2017)

Rulli Nasrullah, "Media Social Perspektif Komunikasi Budaya, dan sosioteknologi", (Bandung:Simbiosa Rekatama Media, 2015)

Hetty, 'Tindak Pidana Perjudian Melalui Internet (Internet Gambling) Ditinjau dari UndangUndang Nomor 11 Tahun 2008 Tentang Informasi dan Transaksi Elektronik”, Majalah ilmiah unikom, Vol 8, No 2

https://kumparan.com/kumparannews/selebgram-di-bengkulu-ditangkap-polisi-karenaoromosikan-judi-online-lu7nGorRmnH/full diakses pada hari Jumat, 11 juni 2021 pukul 20:00 WIB

Undang-undang Republik Indonesia Nomor 19 Tahun 2016 Tentang Perubahan atas UU No 11 Tahun 2008 Tentang Informasi dan Transaksi Elektronik Pasal 27 ayat 2 dan Pasal 45 ayat 1

Budi suhariyanto, ’Tindak Pidana Teknologi Informasi (Cybercrime)", (Jakarta: Rajawali pers, 2019) 